\title{
Bocepreviralapú hármas kezelés hatékonyságának és biztonságosságának retrospektív elemzése elörehaladott fibrosisstádiumú, hepatitis C-vírus 1-es genotípussal fertőzött, korábban sikertelenül kezelt magyar betegeknél
}

\author{
Hunyady Béla dr. ${ }^{1,2}$ - Abonyi Margit dr. ${ }^{3}$ - Csefkó Klára dr. ${ }^{4}$ \\ Gervain Judit dr. ${ }^{5}$ - Haragh Attila dr. ${ }^{1}$. Horváth Gábor dr. ${ }^{6}$ \\ Jancsik Viktor dr. ${ }^{7}$ - Makkai Erzsébet dr. ${ }^{8}$ - Müller Zsófia dr. ${ }^{9}$ \\ Ribiczey Pál dr. ${ }^{10}$ - Sipos Béla dr. ${ }^{11}$ - Szabó Olga dr. ${ }^{12}$ - Szalay Ferenc dr. ${ }^{3}$ \\ Szentgyörgyi László dr. ${ }^{13}$ - Tornai István dr. ${ }^{14}$ - Újhelyi Eszter dr. ${ }^{12}$ \\ Varga Márta dr. ${ }^{4}$. Weisz György dr. ${ }^{7}$. Makara Mihály dr. ${ }^{12}$ \\ 'Somogy Megyei Kaposi Mór Oktató Kórház, Gasztroenterológia Osztály, Kaposvár \\ ${ }^{2}$ Pécsi Tudományegyetem, Klinikai Központ, I. Belgyógyászati Klinika, Pécs \\ ${ }^{3}$ Semmelweis Egyetem, Általános Orvostudományi Kar, I. Belgyógyászati Klinika, Budapest \\ ${ }^{4}$ Réthy Pál Kórház-Rendelőintézet, Békéscsaba \\ ${ }^{5}$ Fejér Megyei Szent György Egyetemi Oktató Kórház, \\ I. Belgyógyászat és Molekuláris Diagnosztikai Laboratórium, Székesfehérvár \\ ${ }^{6}$ Szent János Kórház és Észak-budai Egyesített Kórházak, \\ Hepatológiai Szakrendelés és Budai Hepatológiai Centrum, Budapest \\ ${ }^{7}$ Kenézy Gyula Kórház-Rendelőintézet Egészségügyi Szolgáltató Kft., Debrecen \\ ${ }^{8}$ Magyar Imre Kórház, Ajka \\ ${ }^{9}$ Fejér Megyei Szent György Egyetemi Oktató Kórház, Infektológia, Székesfehérvár \\ ${ }^{10}$ Zala Megyei Kórház, Infektológia, Zalaegerszeg \\ ${ }^{11} J o ́ s a$ András Oktató Kórház Egészségügyi Szolgáltató Nonprofit Kft., Nyíregyháza \\ ${ }^{12}$ Fővárosi Önkormányzat Egyesített Szent István és Szent László Kórház-Rendelőintézet, \\ III. Belgyógyászat, Budapest \\ ${ }^{13}$ Komárom-Esztergom Megyei Önkormányzat Szent Borbála Kórháza, Tatabánya \\ ${ }^{14}$ Debreceni Egyetem, Általános Orvostudományi Kar, Klinikai Központ, Belgyógyászati Intézet, Debrecen
}

\begin{abstract}
Bevezetés: Magyarországon 2011 és 2013 között korai hozzáférési program keretében a forgalmazó jóvoltából 155, döntően elörehaladott fibrosis stádiumú, hepatitis C-vírus l-es genotípussal fertőzött beteg kezdhetett el az akkor számára egyedüli gyógyulási esélyt jelentő boceprevir + pegilált interferon + ribavirin hármas kezelést. Célkitüzés és módszer: A szerző́k a terápia eredményességének és biztonságosságának retrospektív értékelését végezték el egyrészt a kezelés alatti és utáni virológiai válasz, másrészt a súlyos nemkívánatos, illetve terápialeállítást eredményező mellékhatások alapján. Eredmények: Intent-to-treat analízis szerint a 155 betegbő́l 61 beteg vált tartósan vírusmentessé $(39,4 \%)$. A korábbi kettós kezelésre relabáló, parciálisan reagáló, illetve nullreagáló betegek esetében sorrendben $59,5 \%, 41,4 \%$, illetve $22,9 \%$ ( $<<0,05$ a másik két kategóriához képest), míg cirrhosis nélkül $52,5 \%$, cirrhosis esetén $31,3 \%(\mathrm{p}<0,05$ a nem cirrhosisosokhoz képest) volt a tartós virológiai válasz. A legnehezebben kezelhetô cirrhosisos és korábban nullreagáló 33 betegből 6 vált tartósan vírusmentessé (18,2\%). A kezelés idő előtti leállítására elégtelen virológiai válasz miatt a betegek 31,1\%-ánál, mellékhatás miatt 10,3\%-ánál került sor. A súlyos nemkívánatos események gyakorisága 9,8\% volt. Ezek okai: anaemia, hasmenés, depresszió, agranulocytosis, jelentős aminotranszferázemelkedés, generalizált dermatitis és súlyos gingivitis fogvesztéssel, QT-szakasz-megnyúlás az EKG-n, generalizált
\end{abstract}


oedemák és fulladás, uroinfekció, Crohn-betegség fellángolása, Campylobacter pylori-fertőzés és a beteg által nem tolerálható gyengeség/fáradékonyság. Nyolc betegnél volt szükséges transzfúzió, 4 beteg eritropoetin-, 1 pedig granulocytakolónia-stimuláló faktor kezelésben részesült. A programban halálesetet nem jelentettek. Következtetések: A 2011-2013-ban hazánkban elérhető, legkorszerúbbek közé tartozó bocepreviralapú hármas kezeléssel a betegek jelentős része ért el véglegesnek tekinthető vírusmentességet. A kezelések a törzskönyvezési vizsgálatokból megismert eredményességgel és - esetenként súlyos - mellékhatásokkal jártak, amely utóbbiak jelentősen korlátozták a terápia sikerességét. Orv. Hetil., 2016, 157(34), 1366-1374.

Kulcsszavak: boceprevir, direkt ható antivirális szer, genotípus, hepatitis C-vírus, interferon, májrák, májzsugor, vírushepatitis

\section{Efficacy and safety of boceprevir based triple therapy in Hungarian patients with hepatitis $\mathrm{C}$ genotype $\mathbf{l}$ infection, advanced stage fibrosis and prior treatment failure}

Introduction: During 2011 and 2013, 155 Hungarian hepatitis $\mathrm{C}$ genotype 1 infected patients, mostly with advanced liver fibrosis, who did not respond to prior peginterferon + ribavirin dual therapy, started boceprevir based triple therapy in an early access program. Aim and method: Efficacy and safety of the therapy was retrospectively assessed based on sustained virologic responses, as well as on frequency and type of serious adverse events and of those leading to therapy discontinuation. Results: In an intent-to-treat analysis $39.4 \%$ patients $(61 / 155)$ reached sustained virologic response. Amongst pervious relapsers, partial responders and null-responders $59.5 \%, 41.4 \%$ and $22.9 \%(\mathrm{p}<0.05$ compared to the other two categories) reached sustained virologic response, respectively, while amongst non-cirrhotics and cirrhotics $52.5 \%$ and $31.3 \%$ ( $<<0.05$ compared to the non-cirrhotics) achieved sutained virologic response, respectively. Six out of the 33 most difficult to cure patients (previous null responder and cirrhotic) have reached sustained virologic response (18.2\%). Frequency of early discontinuations due to insufficient virologic response was $31.1 \%$, while due to adverse event $10.3 \%$. Reported frequency of serious adverse event was $9.8 \%$. These events represented anemia, diarrhoea, depression, agranulocytosis, elevated aminotransferases, generalized dermatitis and severe gingivitis with loss of teeth, prolonged QT interval on ECG, generalized oedema and severe dyspnoea, uroinfection, exacerbation of Crohn's disease, Campylobacter pylori infection and unacceptable weakness and fatigue. Eight patients received transfusion, 4 patients erythropoietin and 1 granulocyte colony stimulating factor during therapy. No death has been reported. Conclusions: With boceprevir based triple therapy, one of the bests available in 2011-2013 in Hungary, a relevant proportion of hepatitis $\mathrm{C}$ infected patients with advanced liver fibrosis achieved sustained viral response. In this cohort, side-effects resembled those reported in registration studies, and resulted in therapy discontinuation with consequent treatment failure in a relevant number of patients. Efficacy and tolerability of boceprevirbased triple therapy are suboptimal, particularly in the most difficult to cure patient population.

Keywords: boceprevir, direct acting antiviral drug, genotype, hepatitis C virus, hepatocellular cancer, interferon, liver cirrhosis, viral hepatitis

Hunyady, B., Abonyi, M., Csefkó, K., Gervain, J., Haragh, A., Horváth, G., Jancsik, V., Makkai, E., Müller, Zs., Ribiczey, P., Sipos, B., Szabó, O., Szalay, F., Szentgyörgyi, L., Tornai, I., Újhelyi, E., Varga, M., Weisz, Gy., Makara, M. [Efficacy and safety of boceprevir based triple therapy in Hungarian patients with hepatitis $\mathrm{C}$ genotype 1 infection, advanced stage fibrosis and prior treatment failure]. Orv. Hetil., 2016, 157(34), 1366-1374.

(Beérkezett: 2016. június 3.; elfogadva: 2016. június 23.)

\section{Rövidítések}

$\mathrm{BOC}=$ boceprevir; $\mathrm{CHC}=($ chronic hepatitis $\mathrm{C})$ krónikus he patitis $\mathrm{C}$-vírus; $\mathrm{EoTR}=($ end-of treatment virologic response $)$ kezelés végi virológiai válasz; $\mathrm{EVR}=$ (early virologic response $)$ korai virológiai válasz; $\mathrm{Gl}$ = hepatitis $\mathrm{C}$-vírus 1 -es genotípus; $\mathrm{HCC}=$ hepatocellularis carcinoma; HCV = hepatitis C-vírus; IFN = interferon; peg-IFN = pegilált interferon; $\mathrm{PCR}=$ polymerase chain reaction; $\mathrm{SAE}=$ (serious adverse event) súlyos nemkívánatos esemény; SVR = (sustained virologic response) tartós virológiai válasz; TND $=($ target not detectable $)$ nem kimutatható vírus
A hepatitis C-vírus (HCV) a fertőzöttek többségénél krónikus májgyulladást okoz, és évtizedek alatt májzsugort, majd ennek következményeit (májelégtelenség, májrák) eredményezi. A vírus sikeres eradikálása még előrehaladott májfibrosis, cirrhosis stádiumában is lelassítja a progressziót, csökkenti a súlyos következmények veszélyét, a májeredetû halálozást és az összhalálozást [1]. Az egészségnyereség ennél is kifejezettebb lehet korai májfibrosis stádiumában elért gyógyulás esetén.

2014 óta a HCV eradikálására igen hatékony, jól tolerálható interferon (IFN) -mentes kezelési lehetőségek 
állnak rendelkezésre. Azt megelőzően IFN-alapú terápiákat alkalmaztunk $[2,3]$ előbb csak ribavirinnel (RBV), 2011-től direkt ható antivirális szerekkel is kombinálva $[4,5]$. Ez utóbbi lehetőségek egyike a boceprevir + pegilált interferon + ribavirin $(B O C+$ peg-IFN + RBV) hármas kombináció, amellyel a még nem kezelt betegek mintegy kétharmad részénél pusztítható el a vírus. A kezelési esélyek ugyanakkor kedvezőtlenebbek előrehaladott fibrosis stádiumú májbetegeknél, valamint korábbi peg-IFN + RBV kettős kezeléssel meg nem gyógyultaknál [5].

Magyarországon 2011-2013-ban a forgalmazó MSD Pharma Hungary Kft. támogatásával korai hozzáférési programban 155, többségében előrehaladott fibrosis stádiumú, HCV l-es genotípussal (Gl) fertőzött krónikus $\mathrm{C}$-vírus hepatitises $(\mathrm{CHC})$ beteg részesült boceprevir + pegilált interferon + ribavirin $(\mathrm{BOC}+$ pegIFN + RBV) hármas kezelésben (Magyarországi Boceprevir Named Patient Program - H-BNPP). Ezt az akkor létező egyik leghatékonyabb kezelési lehetőséget Európában 2011-ben törzskönyvezték, a program keretében ezek a magyar betegek Európában elsők között juthattak hozzá. (2013. májusban vált szélesebb körben elérhetővé és finanszírozottá.) A programban korábbi peg-IFN + RBV kettős terápiával meg nem gyógyult, szövettani vagy tranziens elasztográfiás vizsgálat alapján F3 vagy F4 fibrosis stádiumú, a kezelést önként vállaló betegek kaphattak esélyt a vírusfertőzés eliminálása révén állapotuk rosszabbodásának megelőzésére, a súlyos következmények elkerülésére.

A Magyar Gasztroenterológiai Társaság Hepatológiai Szekciójának elnöksége 2013-ban határozta el, hogy ebben a jól definiált betegkörben, az egységes kezelési elvek szerinti és jól behatárolt időintervallumban lezajlott kezelések tapasztalatait értékeli. A retrospektív adatgyújtésen alapuló vizsgálatot az ETT TUKEB Etikai Bizottsága engedélyezte (protokollszám: H-BNPP-2014).

$\mathrm{Az}$ adatgyújtés elsődleges célja a BOC + pegIFN + RBV terápia hatékonyságának retrospektív értékelése volt, a kezelés befejezése után 24 héttel is vírusmentes betegek aránya alapján (tartós vírusmentesség-SVR). Értékeltük a kezelés alatti (12. és 24. heti) és kezelés végi virológiai választ, valamint a virológiai sikertelenség gyakoriságát is. A kezelési eredményeket a korábbi kezelési előzmény (relapsus, parciális reagáló, nullreagáló, nem karakterizálható virológiai válasz) és a cirrhosis megléte vagy hiánya szerint is értékeltük.

További célkitűzés volt a hármas kezelés biztonságosságának értékelése a súlyos nemkívánatos események (SAE), a kezelés korai befejezéséhez és/vagy kórházi fekvőbeteg-ellátáshoz vezetó mellékhatások, a legalább 3. fokozatú hematológiai eltérések gyakorisága és a transzfúzióra szoruló betegek száma alapján.

$\mathrm{Az}$ adatgyújtés szempontjait a kezelést végző orvosok konszenzussal határozták meg. A feldolgozás nem terjedt ki valamennyi mellékhatás szisztematikus összegyújtésére, mert a vizsgálatot tervezők szerint az ronthatta volna az elsődleges adatgyúijtés precizitását és csökkenthette volna a kezelő́centrumok adatszolgáltatási hajlandóságát.

\section{Betegek és módszer}

A H-BNPP-ben az arra kvalifikáló és azt önként vállaló betegek a hazai finanszírozott kezelési lehetőség bevezetése előtt, a forgalmazó MSD Pharma Hungary Kft. támogatásával juthattak hozzá a hármas kezelés részét képező boceprevirhez, míg az OEP finanszírozta a peg-INF + RBV komponenseket. Ez utóbbiak két formában álltak rendelkezésre a kezelőorvosok számára: Pegasys + Copegus (Roche Magyarország Kft.), illetve PegIntron + Rebetol (MSD Pharma Hungary Kft.). Nem történt adatgyújtés arra vonatkozóan, ezek melyikét kapták a betegek.

A kezelések befejezését követően retrospektív, nyílt, beavatkozással nem járó, nem összehasonlító, IV. fázisú klinikai vizsgálattal történt a kezelési adatok összegyújjtése, kiértékelése.

A program keretében 2011. augusztus és 2013. május között huszonhat hazai HCV-kezelési centrumban 40 kezelőorvos 155 betege kezdett BOC + peg-IFN + RBV kombinációval hármas kezelést. További négy beteg is engedélyt kapott a kezelésre, de náluk a kezelés állapotrosszabbodás, logisztikai probléma vagy a beteg kívánsága miatt nem kezdődött meg. A kezelés megkezdését megelőzően valamennyi beteg részletes tájékoztatást kapott kezelőorvosától betegségéról és a tervezett terápiáról, valamennyien aláirásukkal igazolták tájékozott beleegyezésüket.

A programban HCV Gl vírussal fertózött, 18. életévüket betöltött, korábban legalább 12 hetes pegIFN + RBV terápiára meg nem gyógyult, olyan krónikus hepatitis C-vírus-betegek kaphattak lehetőséget a kezelésre, akiknek a májmúḱödése kompenzált volt (ChildPugh A stádium), a májbiopszia vagy tranziens elasztográfia Metavir/Knodell F3 (bridging fibrosis) vagy F4 (cirrhosis) stádiumnak megfelelő fibrosist igazolt, a HCV-RNS kvantifikálható, a HCV genotípus meghatározható volt, valamint a részletes orvosi tájékoztatás alapján a kezelést önként vállalták (informed consent). A kezelés feltétele volt továbbá a $\geq 120 \mathrm{~g} / \mathrm{L}$ (nók), illetve $\geq 130 \mathrm{~g} / \mathrm{L}$ (férfiak) hemoglobinszint, a $\geq 1,5 \mathrm{G} / \mathrm{L}$ abszolút neutrophilgranulocyta-szám és a $\geq 100 \mathrm{G} / \mathrm{L}$ thrombocytaszám. Cirrhosis esetén 6 hónapon belüli máj ultrahang- és/vagy CT- és/vagy MR-vizsgálattal a hepatocellularis carcinoma kizárandó volt.

Nem kerülhettek be az adatgyújtésbe azok, akiknél a májbetegséget nem HCV-fertőzés okozta, akik korábban szervátülttetésen estek át (beleértve a májátültetetteket), a HIV- és/vagy HBV-társfertőzöttek, akik megelözően bármilyen HCV ellen direkt ható antivirális szerrel vagy vizsgálati készítménnyel kezelésben részesültek, a dekompenzált májbetegek (Child-Pugh B vagy C stádium), az aktív droghasználók, a napi >20 g alkoholt fo- 
gyasztók, valamint akiknél bármely készítmény vonatkozásában ellenjavallat állt fenn, beleértve a midazolam-, a pimozid-, az amiodaron-, a flecainid-, a propafenon-, a quinidin- és az ergotaminderivátum-készítményeket szedőket (interakciók lehetősége miatt), valamint a Victrelis kapszula valamely összetevőjével szembeni túlérzékenységet mutatókat. A kezelésbe vont betegek demográfiai adatait az 1. táblázat mutatja.

A fibrosis előrehaladottságát a máj szövettani vizsgálata alapján ( 64 betegnél, Metavir F0-F4-es skálán), vagy tranziens elasztográfiával értékeltük (91 betegnél). Utóbbi esetben a 9,6-12,4 kPa közötti májtömöttséget F3 stádiumnak, a 12,5 kPa-t elérő tömöttséget F4 stádiumnak tekintettük [6]. Kivételesen, egyéni rászorultság alapján (foglalkoztatási szempont, szervátültetés szükségessége, cryoglobulinaemia, glomerulonephritis vagy más extrahepaticus HCV-manifesztáció) néhány olyan beteg is lehetőséget kapott a kezelésre, akiknél a máj tömöttsége tranziens elasztográfiával $8,0-9,5 \mathrm{kPa}$ volt

1. táblázat |A boceprevirkezelési programba bevont betegek karakterisztikája

\begin{tabular}{lc}
\hline Demográfiai adatok & \\
\hline Kezelt betegek száma, n & 155 \\
Életkor, átlag (range), év & $58,9(32-74)$ \\
Nő, n (\%) & $79(51,0 \%)$ \\
Testtömeg, átlag (range), kg & $77,4(52,0-110,0)$ \\
\hline Fibrosis stádiuma, n (\%) & $13(8,4 \%)$ \\
\hline F2 vagy F2/F3 átmenet & $46(29,7 \%)$ \\
F3 = bridging fibrosis & $96(61,9 \%)$ \\
F4 = cirrhosis & \\
\hline Kezelési elózmény, n (\%) & $42(27,1 \%)$ \\
\hline Relabáló & $58(37,4 \%)$ \\
Parciális reagáló & $48(31,0 \%)$ \\
Nullreagáló & $7(4,5 \%)$ \\
Nem karakterizálható virológiai válasz & $7(4,5 \%)$ \\
\hline HCV l-es genotípus altípusa, $\mathrm{n}(\%)$ & $126(81,3 \%)$ \\
\hline la & $2(1,3 \%)$ \\
lb & $20(12,9 \%)$ \\
\hline la + lb & \\
Altípus nem ismert/nem tipizálható & $51(32,9 \%)$ \\
\hline Kiinduló vírustiter, n (\%) & $100(64,5 \%)$ \\
\hline$\leq 800000$ NE/ml 800 000 NE/ml & $4(2,6 \%)$ \\
\hline Nem ismert & $57(36,8 \%)$ \\
\hline Hársbetegségek, n (\%) & $28(18,1 \%)$ \\
Diabertonia & $10(6,5 \%)$ \\
\hline Pajzsmirigymúködés-zavar & $10(6,5 \%)$ \\
\hline Depresszió/szorongás & $6(3,2 \%)$ \\
\hline
\end{tabular}

(Metavir F2-nek vagy F2/F3 átmenetnek felelt meg). Az ó adataikat az F3 stádiumú betegekkel összevontan, nem cirrhosisos betegként értékeltük.

A megelőző peg-IFN + RBV kettős kezelés során a virológiai válasz alapján relabálónak tekintettük azt, akinél a korábbi kezelés befejezésekor a HCV-RNS nem volt kimutatható (HCV target not detected - TND), de a követési időszakban ismét kimutathatóvá vált, parciális reagálónak, akinél a korábbi kezelés 12 . hetében a kiindulási HCV-RNS csökkenése elérte a $2 \log _{10}$ mértéket, de a vírus mindvégig kimutatható maradt, és nullreagálónak azt, akinél a csökkenés a korábbi kezeléskor a 12. héten nem érte el a $2 \log _{10}$ mértéket. Néhány beteg esetében a korábbi kezelés során talált virológiai válasz nem volt megítélhető vagy nem állt az erre vonatkozó adat rendelkezésre (nem kategorizálható nem reagálók).

A betegek az alkalmazási előírás és a hazánkban 2011. szeptember 9-én elfogadott konszenzusajánlás szerint 48 hétig heti egyszer peg-IFN-alfa-2a vagy - 2 b (subcutan, sorrendben $180 \mu \mathrm{g}$ vagy $1,5 \mu \mathrm{g} / \mathrm{ttkg}$ ) és ribavirin (per os, sorrendben a testtömeg szerint $75 \mathrm{~kg}$ alatt 1000 mg, 75 kg-tól 1200 mg vagy napi 600-1200 mg, napi két részletre elosztva), valamint a peg-IFN + RBV kettős kezelés 4 . hetét követően emellett 32 (nem cirrhosisos relabáló betegeknél vagy akik a kezelést rosszul tolerálták), illetve 44 hétig (minden további beteg) napi $3 \times 800$ mg boceprevir (Victrelis kapszula, per os, étkezés közben) kezelésben részesültek $[5,7,8]$. Az akkor érvényes hazai HCV-terápiás ajánlás szerint a kezelés leállítandó volt, amennyiben a HCV-RNS mennyisége a kezelés 12. hetét követően meghaladta a $100 \mathrm{NE} / \mathrm{ml}$-t, vagy a kezelés 24. hetében a HCV-RNS kimutatható volt [7, 8]. Mellékhatás miatt az alkalmazási elóírás, az érvényes hazai szakmai ajánlás és/vagy a kezelést végző szakorvos megítélése szerint kerülhetett sor a kezelés leállítására, átmeneti felfüggesztésére vagy a peg-IFN és/vagy az RBV dózisának csökkentésére. (A BOC dózisának csökkentésére az alkalmazási elő́rás szerint nem volt lehetőség.)

A HCV-RNS meghatározása az Egyesített Szent István és Szent László Kórház-Rendelőintézet (Budapest) Immunológiai és Vírusdiagnosztikai Laboratóriumában vagy a Szent György Kórház (Székesfehérvár) Molekuláris Biológiai Laboratóriumában valós idejü polimeráz láncreakcióval (rt-PCR), Ampliprep/TaqMan (Roche, Basel) módszerrel történt, a kezelés megkezdésekor, a kezelés alatt a 12 . és a 24 . héten, a kezelés befejezésekor, valamint azt követően 24 héttel - minden esetben csak akkor, amennyiben a megelőző vizsgálati időpontban elvárt virológiai válasz elmaradása miatt vagy egyéb okból (például mellékhatás) nem vált szükségessé a kezelés leállítása. A HCV-RNS-szint kimutathatóságának és kvantifikálhatóságának küszöbértéke egyaránt $15 \mathrm{NE} / \mathrm{ml}$ volt. A tartós vírusmentesség (SVR) elérésének kritériuma: nem detektálható (TND) vagy kvantifikációs limit alatti (<15 NE/ml) HCV-RNS a kezelés befejezését követően 24 héttel. Az egyéb laboratóriumi vizsgálatokra 
2. táblázat A hematológiai eltérések fokozatának osztályozása

\begin{tabular}{lllll}
\hline $\begin{array}{l}\text { Hematológiai } \\
\text { paraméter }\end{array}$ & $\begin{array}{l}\text { 1. fokozat } \\
(\mathrm{G} / \mathrm{l})\end{array}$ & $\begin{array}{l}\text { 2. fokozat } \\
(\mathrm{G} / \mathrm{L})\end{array}$ & $\begin{array}{l}\text { 3. fokozat } \\
(\mathrm{G} / \mathrm{l})\end{array}$ & $\begin{array}{l}\text { 4. fokozat } \\
(\mathrm{G} / \mathrm{l})\end{array}$ \\
\hline $\begin{array}{l}\text { Anaemia } \\
\begin{array}{l}\text { Thrombo- } \\
\text { cytopenia }\end{array}\end{array}$ & $7,5-<11,0$ & $8,0-<9,5$ & $6,5-<8,0$ & $<6,5$ \\
$\begin{array}{l}\text { Neutropenia } \\
\text { Nen }\end{array}$ & $1,0-<1,5$ & $50-<75$ & $20-<50$ & $<20$ \\
\hline
\end{tabular}

mindenütt helyben került sor. A hematológiai eltérések fokozatát a 2. táblázat szerint értékeltük.

A kezelőorvosok a kezelési adatokat a betegek azonosítására nem alkalmas, személyi azonosítókat nem tartalmazó formában, kóddal ellátva juttatták el az adatfeldolgozást végző centrumba. A betegazonosítókat nem tartalmazó retrospektív adatgyüjtést az ETT TUKEB engedélyezte. A kezelési eredményeket leíró statisztikai módszerekkel értékeltük, a virológiai válaszok vonatkozásában pedig $\chi^{2}$-próbával végeztünk összehasonlítást a különböző kezelési anamnézisû, illetve fibrosis stádiumú betegek között.

\section{Eredmények}

\section{Hatékonyság}

A kezelés 12. és 24. hetében (w12, illetve w24), a befejezésekor (w48) és azt követően 24 héttel (w72) megfigyelt virológiai válaszokat az egyes betegcsoportokban a 3. táblázat mutatja be.

Intent-to-treat analízis alapján a 155 betegból 61 beteg vált tartósan vírusmentessé $(39,4 \%)$. Közülük két betegnél a HCV-RNS a kezelés leállítását követően 24 héttel a kvantifikációs limit alatt kimutatható volt $(<15 \mathrm{NE} /$ $\mathrm{ml}$ ), de későbbi vizsgálatkor nem volt detektálható. Az intent-to-treat analízis kiterjedt egy olyan betegre, akinél a kezelés már a peg-IFN + RBV bevezetó kezelés alatt leállt, valamint két olyan betegre is, akiknél kevesebb mint egy héttel a boceprevir szedése után szakadt meg a kezelés.

Az SVR-arány a relabáló, a parciálisan reagáló, illetve a nullreagáló betegek esetében sorrendben 25/42 $(59,5 \%), 24 / 58(41,4 \%)$, illetve $11 / 48(22,9 \%)$ volt. $\chi^{2}-$ próbával a nullreagálókhoz képest mindkét másik kategóriában szignifikánsan magasabb volt az SVR aránya $(\mathrm{p}<0,05)$. Hét betegnél a korábbi virológiai válasz nem volt kategorizálható, közülük 1 beteg gyógyult meg.

A nem cirrhosisos betegeknél szignifikánsan többen értek el SVR-t, mint a cirrhosisosok közül: 31/59 $(52,5 \%)$ versus $30 / 96(31,3 \%, \mathrm{p}<0,05)$. Az F3 stádiumú betegeknél az SVR-arány 23/46 (50,0\%) volt. A legnehezebben kezelhető cirrhosisos és korábban nullreagáló 33 betegből 6 vált tartósan vírusmentessé (18,2\%).

A kezelés idő előtti leállítására elégtelen virológiai válasz miatt a 12. hetet követő́n 37 betegnél, a 24 . hetet követően további 11 betegnél (együtt 31,1\%), míg mellékhatás miatt $16(10,3 \%)$ betegnél került sor (1. ábra).
A kezelés 24 . hetében 10 betegnél, a 48 . heti befejezéskor további 18 betegnél találtunk vírusáttörést. Tizennégy beteg relabált a kezelés befejezését követően, 10 esetben pedig a kezelés alatti vagy végi HCV-RNSvizsgálatok elmaradása miatt nem volt megítélhető, hogy vírusáttörés vagy relapsus okozta-e a sikertelenséget.

\section{Biztonságosság}

A kezelőorvosok szóbeli tájékoztatása szerint az enyheközepes súlyosságú típusos mellékhatások (gyengeség, fáradékonyság, influenzaszerû tünetek, láz, bőrreakció az injekció helyén, fogyás, hajhullás, ízérzészavar, emésztőszervi panaszok, anaemia stb.) előfordulása igen gyakori volt, lényegében valamennyi betegnél jelentkezett legalább egy ilyen.

A kezelés leállításához vezetố mellékhatások (16/155 beteg, 10,3\%) az alábbiak voltak: 8 esetben anaemia (egyik betegnél egyidejúleg az EKG-n QT-szakasz-megnyúlás, egy másiknál generalizát oedemákkal és fulladással, egy harmadiknál uroinfekcióval), 2-2 esetben depresszió, illetve hasmenés (utóbbiból egyik Campylobacter pylori-fertőzésnek bizonyult), l esetben agranulocytosis, 1 esetben jelentős ALT-emelkedés, 1 esetben generalizált dermatitis és súlyos gingivitis fogvesztéssel, illetve 1 esetben leállítás a beteg döntése alapján, nem tolerálhatónak tartott gyengeség/fáradékonyság miatt. Ezek közül 3 nem merítette ki a súlyos nemkívánatos esemény (SAE) kritériumait, ugyanakkor két betegnél a kezelés késói szakaszában (28., illetve 32. hét) leállított kezelés ellenére tartós vírusmentesség alakult ki.

A kezelés során 15 betegnél $(9,8 \%)$ regisztráltak SAEeseményt: 8 betegnél hospitalizációval járó, transzfúziót igénylő anaemia, 3 betegnél hospitalizációt szükségessé tévő hasmenés (egyiket Crohn-betegség fellángolása, egy másikat Campylobacter pylori-fertózés okozott), 1-1l esetben depresszió, agranulocytosis, illetve generalizált dermatitis, súlyos gingivitis és fogvesztés igényelt kórházi ellátást. Egy betegnél maradandó károsodásként facialis paresis alakult ki (amely nem járt sem hospitalizációval, sem korai kezelésleállítással). A programban halálesetet nem jelentettek.

A 2. táblázat szerinti 3., illetve 4. súlyossági fokozatú anaemiát 12, illetve 4 betegnél (együtt 10,3\%), thrombocytopeniát 9 , illetve 0 betegnél (együtt $5,8 \%$ ), neutropeniát 21, illetve 8 betegnél (együtt 18,7\%) jelentettek. A BOC $(\mathrm{n}=9)$, az RBV ( $\mathrm{n}=11)$ és/vagy a peg-IFN $(\mathrm{n}=6)$ átmeneti kihagyására, az RBV $(\mathrm{n}=74)$ és/vagy a peg-IFN $(\mathrm{n}=52)$ dóziscsökkentésére gyakran volt szükség. Transzfúzióban 8 , eritropoetinkezelésben 4 , granulocytakolónia-stimuláló faktor kezelésben 1 beteg részesült.

\section{Megbeszélés}

Bár a HCV kezelésében az IFN-mentes kezelési lehetôségek bevezetésével 2015-re korszakváltás következett 
Virológiai válasz (HCV-RNS kimutathatósága) a kezelés egyes szakaszaiban a kezelési előzmények, illetve a cirrhosis stádiuma szerint. Az egyes cellákban az adott kategóriába tartozó betegek száma (n) vagy százalékos aránya (\%) került feltüntetésre

\begin{tabular}{|c|c|c|c|c|c|c|c|c|}
\hline Kiinduló paraméter & $\begin{array}{l}\text { Betegszám } \\
\text { (n) }\end{array}$ & $\begin{array}{l}\text { 12. hét előtt } \\
\text { kiesett* }^{*}(\mathrm{n})\end{array}$ & $\begin{array}{l}\text { 12. heti RNS } \\
\text { hiányzik (n) }\end{array}$ & $\begin{array}{l}\text { 12. heti RNS } \\
\text { TND (n) }\end{array}$ & $\begin{array}{l}\text { 12. heti RNS } \\
\text { DET, } \leq 15(\mathrm{n})\end{array}$ & $\begin{array}{l}\text { 12. heti RNS } \\
>15-\leq 100(\mathrm{n})\end{array}$ & $\begin{array}{l}\text { 12. heti RNS } \\
>100(\mathrm{n})\end{array}$ & \\
\hline Összes beteg & 155 & 5 & 0 & 67 & 22 & 24 & 37 & \\
\hline Relabáló & 42 & 2 & 0 & 23 & 8 & 5 & 4 & \\
\hline Parciális reagáló & 58 & 3 & 0 & 24 & 7 & 11 & 13 & \\
\hline Nullreagáló & 48 & 0 & 0 & 17 & 6 & 7 & 18 & \\
\hline $\begin{array}{l}\text { Nem kategorizálható } \\
\text { nem reagáló }\end{array}$ & 7 & 0 & 0 & 3 & 1 & 1 & 2 & \\
\hline Nincs cirrhosis $^{+}$ & 59 & 1 & 0 & 26 & 10 & 10 & 12 & \\
\hline Van cirrhosis & 96 & 4 & 0 & 41 & 12 & 14 & 25 & \\
\hline Kiinduló paraméter & $\begin{array}{c}\text { Betegszám } \\
(\mathrm{n})\end{array}$ & $\begin{array}{l}\text { 24. hét előtt } \\
\text { kiesett* }^{*}(\mathrm{n})\end{array}$ & $\begin{array}{l}\text { 24. heti RNS } \\
\text { hiányzik }(\mathrm{n})\end{array}$ & $\begin{array}{l}\text { 24. heti RNS } \\
\text { TND (n) }\end{array}$ & $\begin{array}{l}\text { 24. heti RNS } \\
\text { DET, } \leq 15(\mathrm{n})\end{array}$ & $\begin{array}{l}\text { 24. heti RNS } \\
>15^{\&}(\mathrm{n})\end{array}$ & & \\
\hline Összes beteg & 155 & 43 & 1 & 89 & 9 & 13 & & \\
\hline Relabáló & 42 & 6 & 1 & 33 & 0 & 2 & & \\
\hline Parciális reagáló & 58 & 16 & 0 & 32 & 5 & 5 & & \\
\hline Nullreagáló & 48 & 19 & 0 & 20 & 4 & 5 & & \\
\hline $\begin{array}{l}\text { Nem kategorizálható } \\
\text { nem reagáló }\end{array}$ & 7 & 2 & 0 & 4 & 0 & 1 & & \\
\hline Nincs cirrhosis $^{+}$ & 59 & 13 & 0 & 39 & 3 & 4 & & \\
\hline Van cirrhosis & 96 & 30 & 1 & 50 & 6 & 9 & & \\
\hline Kiinduló paraméter & $\begin{array}{l}\text { Betegszám } \\
\text { (n) }\end{array}$ & $\begin{array}{l}\text { 48. hét előtt } \\
\text { kiesett* }^{*}(\mathrm{n})\end{array}$ & $\begin{array}{l}\text { 48. heti RNS } \\
\text { hiányzik }(\mathrm{n})\end{array}$ & $\begin{array}{l}\text { 48. heti RNS } \\
\text { TND (n) }\end{array}$ & $\begin{array}{l}\text { 48. heti RNS } \\
\text { DET, } \leq 15(\mathrm{n})\end{array}$ & $\begin{array}{l}\text { 48. heti RNS } \\
>15(\mathrm{n})\end{array}$ & EoTR (\%) & \\
\hline Összes beteg & 155 & 56 & 31 & 55 & 3 & 10 & $46,8 \%$ & \\
\hline Relabáló & 42 & 7 & 14 & 21 & 0 & 0 & $75,0 \%$ & \\
\hline Parciális reagáló & 58 & 21 & 13 & 17 & 3 & 4 & $44,4 \%$ & \\
\hline Nullreagáló & 48 & 25 & 4 & 15 & 0 & 4 & $34,1 \%$ & \\
\hline $\begin{array}{l}\text { Nem kategorizálható } \\
\text { nem reagáló }\end{array}$ & 7 & 3 & 0 & 2 & 0 & 2 & $28,6 \%$ & \\
\hline Nincs cirrhosis ${ }^{+}$ & 59 & 16 & 17 & 21 & 1 & 4 & $52,4 \%$ & \\
\hline Van cirrhosis & 96 & 40 & 14 & 34 & 2 & 6 & $43,9 \%$ & \\
\hline Kiinduló paraméter & $\begin{array}{l}\text { Betegszám } \\
\text { (n) }\end{array}$ & $\begin{array}{l}\text { 48. heti RNS } \\
>15 \text { vagy } \\
\text { kiesett }(\mathrm{n})\end{array}$ & $\begin{array}{l}\text { 72. heti RNS } \\
>15(\mathrm{n})\end{array}$ & $\begin{array}{l}\text { 72. heti RNS } \\
\text { DET, } \leq 15^{\#} \\
(\mathrm{n})\end{array}$ & $\begin{array}{l}\text { 72. heti RNS } \\
\text { TND } \\
(\mathrm{n})\end{array}$ & Nincs SVR (n) & Van SVR (n) & SVR (\%) \\
\hline Összes beteg & 155 & 66 & 30 & 2 & 59 & 96 & 61 & $39,4 \%$ \\
\hline Relabáló & 42 & 7 & 10 & 0 & 25 & 17 & 25 & $59,5 \%$ \\
\hline Parciális reagáló & 58 & 25 & 9 & 1 & 23 & 34 & 24 & $41,4 \%$ \\
\hline Nullreagáló & 48 & 29 & 8 & 1 & 10 & 37 & 11 & $22,9 \%$ \\
\hline $\begin{array}{l}\text { Nem kategorizálható } \\
\text { nem reagáló }\end{array}$ & 7 & 5 & 1 & 0 & 1 & 6 & 1 & $14,3 \%$ \\
\hline Nincs cirrhosis $^{+}$ & 59 & 20 & 8 & 0 & 31 & 28 & 31 & $52,5 \%$ \\
\hline Van cirrhosis & 96 & 46 & 20 & 2 & 28 & 66 & 30 & $31,3 \%$ \\
\hline
\end{tabular}

DET = HCV-RNS detektálható; SVR = sustained virologic response: HCV-RNS a kezelés befejezését követően 24 héttel nem mutatható ki; TND $=$ target not detected: HCV-RNS nem mutatható ki.

$\leq 15, \leq 100,>15,>100$ : HCV-RNS mennyisége NE/ml egységben.

72. hét: kezelés befejezése utáni 24 . hét.

*Az esedékes HCV-RNS-vizsgálat idôpontja előtt kiesett betegeknél nem került sor a későbbi időpontokban a PCR-vizsgálatra.

${ }^{\&}$ Egy korábbi kezeléskor relabáló, nem cirrhosisos beteg később HCV-RNS-negatívvá vált és tartós vírusmentességet ért el (SVR).

\#HCV-RNS később egyik betegnél sem volt kimutatható (SVR).

${ }^{+}$A nem cirrhosisos betegek közül 46 betegnél Metavir F3 fibrosis stádium. 


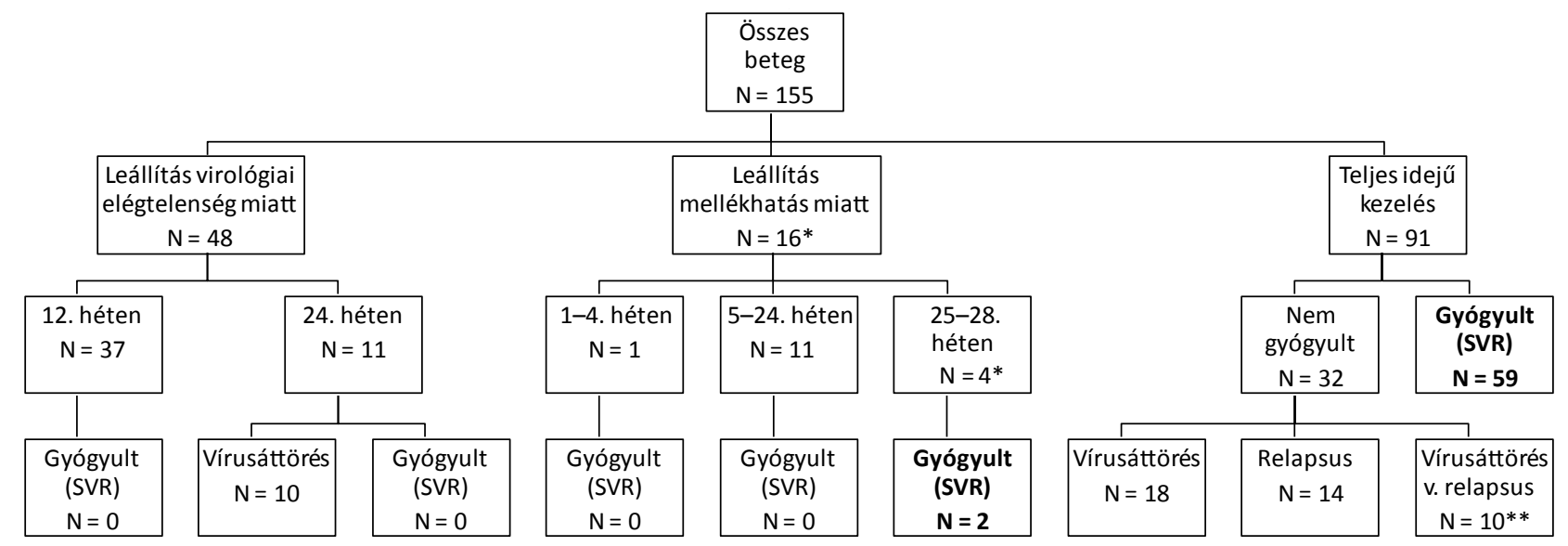

1. ábra $\quad$ A betegek kezelésének kimenetele

*Két beteg tartósan vírusmentessé vált (gyógyult, SVR) a mellékhatás miatt a tervezettnél korábban leállított kezelés ellenére is.

**Tíz beteg esetében a kezelés alatti vagy a kezelés végi HCV-RNS-vizsgálat eredményének hiányában a virológiai sikertelenség formája nem azonosítható

be, a kezelést hosszú ideje végzők és a betegek csaknem ilyen áttörésként élték meg 2011-ben az első, IFN-alapú kombinációkban alkalmazott direkt ható antivirális szerek, a boceprevir és a telaprevir megjelenését. Az ezekkel kapcsolatos várakozás azonban csak részben bizonyult megalapozottnak: mindkét készítmény jelentősen javította a könnyen kezelhető, korábban IFN-terápiában nem részesült, korai fibrosis stádiumú $\mathrm{HCV}$ Gl típussal fertőzöttek gyógyulási esélyeit, ugyanakkor messze elmaradt az optimálistól az arra leginkább rászoruló, korábban IFN-kezelésre rosszul reagáló, előrehaladott fibrosis stádiumú betegek esetében $[9,10]$. Ráadásul éppen ebben a betegkörben jelentkeztek legkifejezettebben azok a mellékhatások, amelyek nemcsak hozzájárultak a kezelés sikertelenségéhez, hanem a betegek egy része számára súlyos (egyes esetekben életveszélyes) állapothoz vezettek [11].

Mindezzel együtt - abban az időben egyéb alternatíva nem lévén - a kezelést végzők csakúgy, mint a finanszírozó úgy ítélték meg, hogy a moderált hatékonyság, a veszélyek és a költségek ellenére is elsősorban az ilyen előrehaladott stádiumú betegek számára szükséges legelőször az IFN-alapú hármas terápiák biztosítása, a még súlyosabb májbetegség és szövődmények kialakulásának megelőzésére. A H-BNPP ezt célozta meg - részben a gyógyszerforgalmazó támogatásával.

A 155 , bocepreviralapú hármas kezelésben részesült beteg kezelési adatainak retrospektív elemzése lényegében a nagy multicentrikus vizsgálatok tapasztalatait erősítette meg, mind a hatékonyság, mind a mellékhatások vonatkozásában. A 61 vírusmentessé vált beteg számára a program - nehézségeivel együtt - elérte a hőn áhított sikert: a vírus eliminálását. Ez pedig klinikai vizsgálatokkal igazoltan kedvezőbb hosszú távú kimenetelre adhat esélyt: megállhat a betegség progressziója, megnövekedhet a várható élettartam, elkerülhetôvé válhatnak a májcirrhosis súlyos szövődményei, így a hepaticus ence- phalopathia, az ascites, a májrák; egyúttal csökkenhet a HCV-vel kapcsolatos és összhalálozás, enyhülhetnek a későbbi egyéni és össztársadalmi betegségterhek. Egyértelmúen megállapítható, hogy a májcirrhosis jelenléte vagy a korábbi nullreagáló IFN-válasz kedvezőtlen gyógyulási esélyt jelentett a bocepreviralapú hármas kezeléskor.

A H-BNPP keretében kezelt betegeknél talált SVRarányok nem hasonlíthatók érdemben össze a Respond-2 törzskönyvezési vizsgálat eredményeivel, mert ez utóbbiban egyrészt különböző fibrosis stádiumú betegeknél került sor sikertelen peg-IFN + RBV kettős kezelés után ismételt $\mathrm{BOC}+$ peg-IFN + RBV kezelésre, másrészt nem vehettek részt benne nullreagáló betegek [9]. Nem egyezett meg teljesen az általunk kezelt betegpopuláció a Provide vizsgálatban BOC + peg-IFN + RBV kezelésben részesült nullreagáló betegpopulációval sem, hiszen közülük csak 3 betegnek volt cirrhosisa [10]. Így az itt közölt adatok kiegészítik korábbi ismereteinket az előrehaladott fibrosis stádiumú, korábban sikertelenül kezelt HCV Gl-fertőzött betegekre vonatkozóan.

Az itt közölttől eltért a francia Compassionate Use of Protease Inhibitors in Viral C Cirrhosis (CUPIC) kezelési program is, amelyben 511 , korábban peg-IFN + RBV kezeléssel meg nem gyógyult (44,3\% relabáló vagy vírusáttörést mutató, 44,8\% parciális reagáló, 8,0\% nullreagáló) HCV Gl-fertőzött kompenzált májcirrhosisos betegnél telaprevir esetében $(\mathrm{n}=299)$ sorrendben $74,2 \%$, $40,0 \%$ és $19,4 \%$, míg boceprevir esetén $(\mathrm{n}=212) 53,9 \%$, $38,3 \%$ és $0 \%$ SVR12-t értek el [11]. A CUPIC vizsgálatban alacsony volt a nullreagálók száma, ugyanakkor csak cirrhosisos betegek kerülhettek be, akik között jelentős számban voltak olyanok, akik a betegség elörehaladott volta miatt (például cytopenia, korábbi varixvérzés) a törzskönyvezési vizsgálatokban nem juthattak volna kezeléshez. Nem meglepő módon a betegek felénél $(49,9 \%)$ jelentkezett súlyos nemkívánatos esemény (fö- 
ként hepaticus dekompenzáció és/vagy súlyos fertőzés), és a kezelteknél 2,2\% volt a mortalitás. A boceprevirre vonatkozóan a H-BNPP esetében a CUPIC-adatoknál kedvezőbb kezelési és biztonságossági eredményekről tudunk beszámolni. Mindkettő hátterében szerepe lehet a körültekintőbb betegbeválasztásnak, és a jól kontrolállt, hazai szakmai ajánlás szerint végzett kezelésnek.

Az ugyanabban az időszakban törzskönyvezett másik proteázgátlóval lefolytatott, magyar betegek kezelését is lehetővé tévő vizsgálatban a telaprevir + peg-IFN + RBV kezelés hatékonyságát korábbi kezeléskor relabáló, parciális reagáló, illetve nullreagáló, HCV Gl vírussal fertőzött betegeknél sorrendben 71,9\%, 55,4\%, illetve 33,7\%nak találták [12]. Ez az eredmény némiképpen meghaladja az általunk bocepreviralapú hármas kezeléssel talált eredményeket. Az egymástól függetlenül végzett, nem összehasonlítási céllal lefolytatott kezelések alapján nyert eredmények ugyanakkor nem teszik lehetővé a kezelési stratégiák érdemi összehasonlítását, hiszen mind a kezelt betegek, mind a kezelést végzők és lehetőségeik eltérhettek egymástól. Mindkét proteázgátlóval kiegészített IFN-alapú kombináció hatékonysága jelentősen elmarad a 2015-re forgalomba került IFN-mentes kombinációs kezelésekkel elérhető hatékonyságtól (>90\% valamennyi betegcsoportban), különösen a legnehezebben kezelhető, korábbi kezelésre nullreagáló cirrhoticus betegek esetében (vizsgálatunkban 18,2\% SVR). Fontos annak hangsúlyozása, hogy - amellett, hogy szakmai szempontból valamennyi HCV-fertőzött beteg esetében az IFN-mentes kezelések a leghatékonyabbak és legbiztonságosabbak - különösen indokolt ezek használata a korábban IFN-alapú terápiával sikertelenül kezelt és/vagy elörehaladott fibrosis stádiumú betegeknél.

A programban kezelt betegek száma és az adatgyújtés retrospektív jellege nem adott lehetőséget arra, hogy az ismert vagy feltételezett valamennyi prediktív faktor egyenkénti súlyát elemezzük vagy multivariancia-analízist végezzünk. Finanszírozási és/vagy technikai nehézségek miatt nem kerülhetett sor az IL28B-polimorfizmus, a kezelés 8 . hetében a virológiai válasz és az inzulinrezisztencia szisztematikus elemzésére. Nem álltak rendelkezésre adatok INR és szérumalbumin vonatkozásában sem.

A H-BNPP tehát elsők között tette lehetővé az akkor más módon gyógyulási eséllyel nem rendelkező 155 HCV Gl-fertőzött magyar beteg számára a bocepreviralapú hármas kezelést, és közülük 61 számára vírusmentességet eredményezett. Bár az idő a két legkorábbi, HCV ellen direkt ható antivirális szert azóta hazánkban is túlhaladta, a kezelési tapasztalatok összegzése és közlése nem veszített fontosságából.

\section{A H-BNNP keretében adatot szolgáltató kezelőorvosok (betegszám, munkahely)}

Abonyi Margit ( $\mathrm{N}=8$; Semmelweis Egyetem, I. Belgyógyászati Klinika, Budapest), Bali Ildikó ( $\mathrm{N}=1$; Tolna
Megyei Balassa János Kórház, Szekszárd), Bányai Tiva$\operatorname{dar}(\mathrm{N}=3$; Békés Megyei Pándy Kálmán Kórház, Gyula), Csefkó Klára ( $\mathrm{N}=5$; Réthy Pál Kórház-Rendelőintézet, Békéscsaba), Csöndes Mihály $(\mathrm{N}=2$; Petz Aladár Megyei Oktató Kórház, Győr), Fried Katalin ( $\mathrm{N}=2$; Fővárosi Önkormányzat Egyesített Szent István és Szent László Kórház-Rendelőintézet, Budapest), Gasztonyi Beáta ( $\mathrm{N}=4$; Zala Megyei Kórház, Zalaegerszeg), Gervain Judit ( $\mathrm{N}=5$; Fejér Megyei Szent György Kórház, Székesfehérvár), Haragh Attila ( $\mathrm{N}=5$; Somogy Megyei Kaposi Mór Oktató Kórház, Kaposvár), Hausinger Péter ( $\mathrm{N}=1$; Bács-Kiskun Megyei Önkormányzat Kórháza, Kecskemét), Horváth Gábor ( $\mathrm{N}=9$; Fővárosi Önkormányzat Szent János és Észak-budai Egyesített Kórházai, Budapest), Hunyady Béla ( $\mathrm{N}=5$; Somogy Megyei Kaposi Mór Oktató Kórház, Kaposvár és Pécsi Tudományegyetem, Pécs), Jancsik Viktor ( $\mathrm{N}=9$; Kenézy Gyula Kórház-Rendelőintézet, Debrecen), Karádi László $(\mathrm{N}=1$; Borsod-Abaúj-Zemplén Megyei Kórház és Egyetemi Oktató Kórház, Miskolc), Lakner Lilla $(\mathrm{N}=1$; Vas Megyei Markusovszky Kórház, Szombathely), Lengyel Gabriella ( $\mathrm{N}=1$; Semmelweis Egyetem, II. Belgyógyászati Klinika, Budapest), Lesch Miklós ( $\mathrm{N}=3$; Jósa András Oktató Kórház, Nyíregyháza), Makara Mihály ( $\mathrm{N}=10$; Fővárosi Önkormányzat Egyesített Szent István és Szent László Kórház-Rendelőintézet, Budapest), Makkai Erzsébet ( $\mathrm{N}=5$; Magyar Imre Kórház, Ajka), Martyin Tibor ( $\mathrm{N}=3$; Békés Megyei Pándy Kálmán Kórház, Gyula), Müller Zsófia (N = 7; Fejér Megyei Szent György Kórház, Székesfehérvár), Nemesi Krisztina ( $\mathrm{N}=$ 3; Fővárosi Önkormányzat Egyesített Szent István és Szent László Kórház-Rendelőintézet, Budapest), Palatka Károly $(\mathrm{N}=3$; Debreceni Egyetem, II. Belgyógyászati Klinika, Debrecen), Pár Alajos ( $\mathrm{N}=3$; Pécsi Tudományegyetem, I. Belgyógyászati Klinika, Pécs), Péterfi Zoltán ( $\mathrm{N}=1$; Pécsi Tudományegyetem, I. Belgyógyászati Klinika, Pécs), Ribiczey Pál ( $\mathrm{N}=6$; Zala Megyei Kórház, Zalaegerszeg), Schneider Ferenc ( $\mathrm{N}=3$; Vas Megyei Markusovszky Kórház, Szombathely), Schuller János $(\mathrm{N}=2$; Fővárosi Önkormányzat Egyesített Szent István és Szent László Kórház-Rendelőintézet, Budapest és Uzsoki Utcai Kórház, Budapest), Sipos Béla ( $\mathrm{N}=5$; Jósa András Oktató Kórház, Nyíregyháza), Szabó Anna $(\mathrm{N}=1$; Jász-Nagykun-Szolnok Megyei Hetényi Géza Kórház-Rendelőintézet, Szolnok), Szabó Olga ( $\mathrm{N}=6$; Fővárosi Önkormányzat Egyesített Szent István és Szent László Kórház-Rendelőintézet, Budapest), Szentgyörgyi László ( $\mathrm{N}=6$; Komárom-Esztergom Megyei Önkormányzat Szent Borbála Kórháza, Tatabánya), Takács Andrea ( $\mathrm{N}=1$; Magyar Imre Kórház, Ajka), †Telegdy László ( $\mathrm{N}=1$; Fővárosi Önkormányzat Egyesített Szent István és Szent László Kórház-Rendelőintézet, Budapest), Tolvaj Gyula ( $\mathrm{N}=2$; Magyar Honvédség Egészségügyi Központ, Budapest), Tornai István ( $\mathrm{N}=3$; Debreceni Egyetem, II. Belgyógyászati Klinika, Debrecen), Tóth Tamás ( $\mathrm{N}=4$; Semmelweis Egyetem, Budapest), Tusnádi Anna ( $\mathrm{N}=3$; Jász-Nagykun-Szolnok 
Megyei Hetényi Géza Kórház-Rendelőintézet, Szolnok), Varga Márta ( $\mathrm{N}=6$; Réthy Pál Kórház-Rendelőintézet, Békéscsaba), Weisz György ( $\mathrm{N}=6$; Kenézy Gyula Kórház-Rendelőintézet, Debrecen).

Anyagi támogatás: A retrospektív vizsgálatot a szerzők tervezték meg és végezték el, de a vizsgáló által kezdeményezett és lefolytatott klinikai vizsgálatban végzett adatgyüjtéshez és a statisztikai adatfeldolgozáshoz az MSD Pharma Hungary Kft. anyagi támogatást nyújtott.

Szerzői munkamegosztás: H. B., M. M.: Betegadatok szolgáltatása, a vizsgálati terv kialakítása, adatfeldolgozás, a kézirat elkészítése. H. G., Sz. F., T. I.: Betegadatok szolgáltatása, a Hepatitis Terápiás Bizottságban a kezelési engedélyek elbírálása, a kézirat véleményezése, véglegesítése. G. J., Ú. E.: A molekuláris diagnosztikai vizsgálatok elvégzése és ezek eredményének összegyứjtése. G. J.: A kézirat véleményezése, véglegesítése, betegadatok szolgáltatása. A. B., Cs. F., H. A., J. V., M. E., M. Zs., R. P., S. P., Sz. O., Sz. L., V. M., W. Gy.: A vizsgálati terv kialakítása, a társszerzőség feltételeként előzetesen konszenzussal megállapított legalább 5 beteg adatainak szolgáltatása. A cikk végleges változatát valamennyi szerző elolvasta és jóváhagyta.

Érdekeltségek: G. J., H. G., H. B., M. M., Sz. F., T. I., V. M.: Tanácsadói/előadói/szakértői és/vagy klinikai vizsgálói díjazásban részesült az AbbVie, a Bristol-Myers Squibb, a Boehringer Ingelheim, a Fresenius Kabi, a Gilead Sciences, a Janssen-Cilag, az MSD/Merck Sharp \& Dohme, a Novartis és/vagy a Roche vállalatok részéról. A további társszerzők érdekeltséget nem jelentettek be.

\section{Köszönetnyilvánítás}

A szerzők és a Magyar Gasztroenterológiai Társaság Hepatológiai Szekciója elnöksége köszönetüket fejezik ki a programban részt vevó betegeknek és családtagjaiknak, az adatot szolgáltató kezelőorvosoknak, az MSD Pharma Hungarynak a boceprevir térítésmentes elérhetővé tételéért és az adatgyújjtéshez és -feldolgozáshoz nyújtott támogatásért, valamint Hunyady Péternek az adatfeldolgozásért.

\section{Irodalom}

[1] Van der Meer, A. J., Veldt, B. J., Feld, J. J., et al.: Association between sustained virological response and all-cause mortality among patients with chronic hepatitis $\mathrm{C}$ and advanced hepatic fibrosis. JAMA, 2012, 308(24), 2584-2593.
[2] European Medicines Agency: Pegasys. Instructions for use. [Pegasys. Alkalmazási előírás.] 12/12/2014. http://www.ema. europa.eu/docs/hu_HU/document_library/EPAR_-_Product_Information/human/000395/WC500039195.pdf [Hungarian]

[3] European Medicines Agency: PegIntron. Instructions for use. [PegIntron alkalmazási elő́rás.] 11/06/2014. http://www. ema.europa.eu/docs/hu_HU/document_library/EPAR_-_ Product_Information/human/000280/WC500039388.pdf [Hungarian]

[4] European Medicines Agency: Incivo. Instructions for use. [Incivo alkalmazási elő́rás.] 13/08/2015. http://www.ema.europa. $\mathrm{eu} /$ docs/hu_HU/document_library/EPAR_-_Product_Information/human/002313/WC500115529.pdf [Hungarian]

[5] European Medicines Agency: Victrelis. Instructions for use. [Victrelis alkalmazási elóírás.] 09/03/2015. http://www.ema. europa.eu/docs/hu_HU/document_library/EPAR_-_Product_Information/human/002332/WC500109786.pdf [Hungarian]

[6] Horváth, G.: New non-invasive tool for assessment of liver fibrosis: transient elastography. [A májfibrosis meghatározásának új, noninvazív módszere: tranziens elasztográfia (FibroScan).] Orv. Hetil., 2011, 152(22), 860-865. [Hungarian]

[7] Makara, M., Horváth, G., Gervain, J., et al.: Hungarian consensus guideline for the diagnosis and treatment of $\mathrm{B}, \mathrm{C}$, and $\mathrm{D}$ viral hepatitis. [Ajánlás a B-, a C- és a D-vírus hepatitisek diagnosztikájára és antivirális kezelésére.] Orv. Hetil., 2012, 153(10), 375-394. [Hungarian]

[8] Hunyady, B., Gervain, J., Horváth, G., et al.: Diagnosis, antiviral treatment and post-treatment follow up of hepatitis $\mathrm{C}$ virus infection. Consensus guideline. [C-vírus-hepatitis diagnosztikája, antivirális kezelése, kezelés utáni gondozása. Szakmai konszenzusajánlás.] Magyar Belorvosi Archivum, 2012, 65(4), 214-234. [Hungarian]

[9] Bacon, B. R., Gordon, S. C., Lawitz, E., et al.: Boceprevir for previously treated chronic HCV genotype 1 infection. N. Engl. J. Med., 2011, 364(13), 1207-1217.

[10] Vierling, J. M., Davis, M., Flamm, S., et al.: Boceprevir for chronic HCV genotype 1 infection in patients with prior treatment failure to peginterferon/ribavirin, including prior null response. J. Hepatol., 2014, 60(4), 748-756.

[11] Hézode, C., Fontaine, H., Dorival, C., et al.: Effectiveness of telaprevir or boceprevir in treatment-experienced patients with HCV genotype 1 infection and cirrhosis. Gastroenterology, 2014, 147(1), 132-142.e4.

[12] Colombo, M., Strasser, S., Moreno, C., et al.: Sustained virological response with telaprevir in 1,078 patients with advanced hepatitis C: the international telaprevir access program. J. Hepatol., 2014, 61(5), 976-983.

(Hunyady Béla dr., Kaposvár, Tallián Gyula u. 20-32., 7400 e-mail: bhunyady@yahoo.com) 